\title{
Prevention of Nosocomial Infection through Application of Housekeeping
}

\author{
Qomariyatus Sholihah, Aprizal Satria Hanafi \\ Public Health Department, Faculty of Medicine, Universitas Lambung Mangkurat, Indonesia
}

\begin{tabular}{|c|c|}
\hline Article Info & ABSTRACT \\
\hline Article history: & \multirow{8}{*}{$\begin{array}{l}\text { The hospital has a high risk of nosocomial infection. Nosocomial infection } \\
\text { can infect patients in hospital and can inhibit the patient's recovery, even } \\
\text { worsen a patient. The purpose of this study was to determine the relationship } \\
\text { of the application of housekeeping with the total number of germs floor as } \\
\text { prevention nosocomial infection in the treatment room Roses in Ulin } \\
\text { Hospital Banjarmasin, Indonesia. The study design was observational } \\
\text { analytic. The study population was all Roses class treatment rooms. The } \\
\text { samples were taken from the floor germs } 4 \text { point class treatment rooms in } \\
\text { hospitals Rose Ulin. Sampling was conducted in the first week and the } \\
\text { second week in November } 2015 \text {. Paired t-test results showed no relationship } \\
\text { between the applications of housekeeping with the total number of germs } \\
\text { floor with a p-value } 0.015 \text {. This study found there was decreasing the total } \\
\text { number of germ on the floor in all rooms. It is hoped that the hospital to } \\
\text { continue to pay attention to the condition of the hospital, especially in terms } \\
\text { of hygiene in order to avoid transmission of germs or nosocomial infections } \\
\text { due to bacteria originating from the floor. }\end{array}$} \\
\hline Received Sep 25, 2016 & \\
\hline Revised Dec 03, 2016 & \\
\hline Accepted Jan 15, 2017 & \\
\hline Keyword: & \\
\hline Bacteria & \\
\hline Housekeeping & \\
\hline Nosocomial Infection & \\
\hline
\end{tabular}

Copyright $\odot 2017$ Institute of Advanced Engineering and Science. All rights reserved.

\section{Corresponding Author:}

Aprizal Satria Hanafi,

Public Health Department, Faculty of Medicine,

Lambung Mangkurat University,

A. Yani Km. 36 Road, Banjarbaru City, Indonesia 70711.

Email: aprizalsatriahanafi@gmail.com

\section{INTRODUCTION}

Patient safety is part of the quality of hospital services. Many unsafe conditions are obtained when the patient is in the hospital. One of the unsafe conditions that can threaten the safety of patients is germs in hospitals [1]. The hospital is a health care institution for the community. Based on the understanding that the hospital can be considered as a gathering place for all kinds of diseases both infectious and non-infectious, so it can have negative impacts such as: 1) delays the healing process and recovery of the patient; 2) transmission of the disease to health care workers; 3) transmit the disease to the surrounding community; and 4) cause environmental pollution around the hospital [2].

Germ is an organism that was the most numerous and widespread compared to other organisms. Germ can act as pollutants, both outdoors and indoors. The spread of germs can happen anywhere, not least in the hospital environment. One of the spread of germs are hospital floor [3]. Cleanliness of floors greatly affect the incidence of nosocomial infections in hospitals [4]. Types of microorganisms are often potentially nosocomial infection are: Proteus sp., Escherichia coli, Staphylococcus aureus, Candida albicans, and Pseudomonas aeruginosa [5].

Nosocomial infection is a type of infection that occurs in hospital. This infection causes 1.4 million deaths every day worldwide. Additionally, the WHO in Elizabeth, et al also conducted a study that showed that about $8.7 \%$ of the 55 hospitals of 14 countries from Europe, Middle East, Southeast Asia and the Pacific showed a nosocomial infection and to Southeast Asia as much as $10.0 \%$ [6]. In Indonesia, nosocomial 
infections reached $15.74 \%$, far above the developed countries that only 4.8 to $15.5 \%$ [5]. Nosocomial infections can cause older patients treated at the Hospital. Data incidence of nosocomial infections in developing countries is not so clear. The numbers just came from several studies in several hospitals [7]. Nosocomial infection is a health care problem that often occurs. Nosocomial infections cause increased morbidity and mortality, additional days of treatment, and increase the cost of care [8].

Some incidence of nosocomial infection may not cause the patient's death, but leads to longer patient treated in hospital [9], [10]. One effort to prevent nosocomial infections is by paying attention to sanitary aspects. Management of hospital sanitation is important to note, because the hospital is a health-care facilities for the general public. Environmental sanitation hospitals in controlling the growth of microorganisms can be accomplished through sterilization [11].

Sanitary installations hospitals, especially in the disinfection activities have a duty and responsibility to supervise and disinfection measures examination room, operating room, treatment room and an isolation room in an effort to prevent nosocomial infections [12]. Disinfection is an attempt to reduce the number of disease-causing microorganisms or potential pathogens such as bacteria, viruses, parasites and fungi [13], [14]. According to Krisetyowati, disinfection of hospital care room floor to do with Refisol. Mopping the floor using Refisol shown to decrease the number of bacteria in a hospital room floor [12].

Ulin Hospital Banjarmasin is the hospital doing medical activity. According to the annual report of the 10 diseases in Hospital Ulin Banjarmasin, especially in the Mawar room. The results of the examination conducted by Ulin Hospital said that the total number of germs on the floor of the treatment room in Ulin Hospital is $16 \mathrm{CFU} / \mathrm{cm}^{2}$. This already exceeds the existing standards for total bacteria in the room which is about 5-10 CFU / $\mathrm{cm}^{2}$. This is feared to cause nosocomial infections.

Contaminations of germs not only come from the patient or attendant. Pollution also comes from the environment such as air, floors, walls, water, foods and tools used [14]. Various actions may be taken to address the problem of pollution caused by the bacteria in the hospital, one of them by improving sanitation in hospitals. Implementation of sanitation is done by applying housekeeping. Based on the above researchers are interested to know the relationship of housekeeping application for prevention of nosocomial infection at the Mawar room treatment in the Ulin Hospital Banjarmasin.

\section{RESEARCH METHOD}

The study design was observational analytic. The object of this study is the number of bacteria on the floor throughout the Mawar treatment room at Hospital Ulin Banjarmasin. Sample is germs floor that take form 4 point in Rose treatment room at Ulin Hospitals Banjarmasin.

The study population was all class Roses treatment room. Samples are germs floor taken from the 4 point class Rose treatment room at Ulin Hospital Banjarmasin. Sampling was conducted in the first week and the second week of November 2015. The independent variable in this research is the application of housekeeping and the dependent variable is the total number of germs floor. Materials used in this study is the blood agar media, $\mathrm{NaCl}$, ice cube and isolates germs from the floor of the Roses treatment room floor in Ulin Hospitals Banjarmasin are grown in media isolation.

The instrument used in this study is a sterile swab, petri plates, test tubes, Bunsen lamps, flasks, incubator, aluminum foil autoclave model no 1925 X, laminary flow and colony counter Struart scientific. Sampling was conducted by using a cotton swab stick sterile floor at 4 points with a size of $1 \mathrm{~cm}^{2}$ for every point. Sterile cotton stick dipped in $0.9 \% \mathrm{NaCl}$ and then applied to the floor, the aluminum foil covering the plate was then opened, then apply a sterile cotton into Petri dishes containing blood agar media with zigzag manner. After it closed petri dish with aluminum foil, a petri dish containing the sample is then transported to the laboratory by using a flask containing ice.

Further planting and breeding blood agar medium that has been planted and then incubated at $37^{\circ} \mathrm{C}$ for 18-24 hours. Then measuring the colonies of bacteria that grow on blood agar media and numbered by using colony counter. Data are collected, processed and analyzed descriptively and presented in a frequency distribution table. The bivariate analysis performed using the statistical method which paired $\mathrm{T}$ test with significance level $\alpha=0.05$ to determine the relationship of the application of housekeeping with the total number of germs floor.

\section{RESULTS AND ANALYSIS}

\subsection{Univariate Analysis}

The focus of the research are total number of germs floor before and after implementation of housekeeping in the Roses treatment room Hospitas Ulin Banjarmasin. Table 1 shows the differences in the 
number of germs in the 4 treatment rooms before and after the implementation of housekeeping. Data showed all the rooms has decreased the number of germs floor after implementation of housekeeping.

Table 1. Frequency Distribution of Germs Floor Score

\begin{tabular}{ccc}
\hline Room & Result (Before) & Result (After) \\
\hline 3 & $11 \mathrm{CFU} / \mathrm{cm}^{2}$ & $1 \mathrm{CFU} / \mathrm{cm}^{2}$ \\
5 & $12 \mathrm{CFU} / \mathrm{cm}^{2}$ & $1 \mathrm{CFU} / \mathrm{cm}^{2}$ \\
6 & $10 \mathrm{CFU} / \mathrm{cm}^{2}$ & $2 \mathrm{CFU} / \mathrm{cm}^{2}$ \\
9 & $16 \mathrm{CFU} / \mathrm{cm}^{2}$ & $4 \mathrm{CFU} / \mathrm{cm}^{2}$ \\
\hline
\end{tabular}

Source: Primary Data

\subsection{Bivariate Analysis}

The results of the bivariate analysis done is paired $\mathrm{T}$ test to determine the relationship between the application of housekeeping (independent variable) with the total number of germs floor (the dependent variable) can be seen in Table 2.

Table 2. The Relationship between Application of Housekeeping with Score of Germs Floor

\begin{tabular}{ccccc}
\hline Variabel & Mean & $\begin{array}{c}\text { Paired Differences } \\
\text { Std. Deviation }\end{array}$ & Std. Error Mean & Sig. (2-tailed) \\
\hline Germs1 Germs2 & 11.311 & 2.806 & .935 & .015 \\
\hline
\end{tabular}

Paired T test results with a confidence level of $95 \%$ to get the value of $\mathrm{p}=0.015$. $\mathrm{P}$ value of statistical test results obtained in Ho decision rejected ( $p$ value $<0.05$ ), which means there is a relationship between the application of housekeeping with total number of germs floor. The problem of nosocomial infection is a major problem in every hospital [15]. This is even more troubling, because nosocomial infections can increase morbidity, mortality, financial loss and the duration of hospital care [16], [17]. The hospital environment is always in contact with humans, in this case the hospital personnel, patients and the various ways either direct or indirect contact with air or intermediary vectors [18]. Germs flooring risk causing nosocomial infection in patients [19].

According Quinn et al studies, the factors that influence the number of bacteria on the floor of the treatment room one of them is the frequency of cleaning the floor [20]. Decrease in number of bacteria caused by the application of housekeeping floor with a mop floor Rose room treatment on a daily basis. After treatment for a few days decreased number of bacteria floor based on the results of laboratory tests.

Based on the Ministry of Health Republic of Indonesia 1204 / Menkes / SK / X / 2004 about the Hospital Healthy Environment Standard maximum total number of germs in the floor of the treatment room is 5-10 CFU $/ \mathrm{cm}^{2}$ [21]. Figures floor germs that exceed the requirements of the hospital environment can trigger nosocomial infections. Appropriate measures necessary to prevent nosocomial infections in hospitals, one of which is to conduct regular disinfection.

In the hospital there are sick people who carry germs and are potential sources of infection for others. In an effort to tackle the incidence of nosocomial infections, a review of the epidemiology of the problem of contamination and nosocomial infection needs to be done because it is basically the incidence of nosocomial infections involving the human element, the environment and microbes, which are inter-related to each other [22].

The high number of bacteria floors can be caused by various factors such as the use of disinfectant dose is not appropriate, how to use a disinfectant that is not good and mopping the floor that is not done routinely [23], [24]. Additionally, the high number of bacteria floor was also influenced by other factors such as patients, visitors, animals and insects as well as the air. Giving disinfectant on the floor will kill microorganisms that can cause disease. Appropriate disinfectant dosing would reduce the number of germs in the hospital floor. These germs can live and thrive on the floor of the hospital [25], [26].

Disinfection is an effort to reduce / eliminate the amount of pathogenic microorganisms that cause disease (not including spores) [27]. Mopping with a disinfectant is an attempt to clean the floor with a way to chemically reduce and eliminate the pathogenic microorganisms that cause disease [28]. Application of housekeeping will create a work environment that is clean, hygienic, and safe. Besides useful for the implementation of hospital housekeeping can also help employees achieve personal discipline. Quality of the work must be guaranteed as early as possible in the workplace. Improve work efficiency and reduce operating costs [29]. 
One of the principles that can be applied housekeeping is cleaning by killing germs on the floor of the treatment room to perform disinfection. Disinfection can be done to mop floors with a disinfectant containing $\mathrm{NaOH}$ and Banzalkonium Chloride has the ability to kill germs. $\mathrm{OH}$ ions of sodium hydroxide are ionized in the water as a disinfectant (germ killers). Given the hospital as a place that is prone to germs, spraying is required in a hospital environment to eliminate the total number of germs on the floor of the hospital [12], [30].

Additionally disinfection treatment room floor can be made using disinfectant phenol $1 \%$. Ammonium kuatener is one disinfecting floors and an aldehyde-free active against bacteria, micro-bacteria, fungi, viruses (HBV, HIV, HCV, rota, adeno, papova, Noro). The floor area of the hospital is also on the wane and is not eligible health with the increasing number of visitors resulting in increased number of bacteria on the floor [31],[32]. Increased number of bacteria floor will trigger a nosocomial infection. Nosocomial infections will increase health care costs due to the increased length of stay in hospital, treatment with expensive drugs (such as antiretroviral drugs for HIV / AIDS, and antibiotics), and the use of other services (such as laboratory tests, rontsen, transfusion). Consequently, in countries with low resources, prevention of nosocomial infection should be considered much more important in the effort to improve health services in hospitals and other healthcare facilities will be made [33],[34].

Hospital environment unfavorable will allow the transmission of a disease that will affect public health in the hospital environment. Therefore, hospital sanitation services should be organized in order to create a clean environment so it can support the healing of patients and can prevent the transmission of nosocomial infections in the hospital environment.

\section{CONCLUSION}

Based on the results of laboratory tests the total number of germs on the floor of the 3 Rose's treatment room, Hospital of Ulin Banjarmasin has met the environmental standards of health services after the implementation housekeeping. After application of housekeeping there is a decrease in the total number of germs on the floor. The results of the bivariate analysis using paired $\mathrm{T}$ test also showed that there are differences in the number of the total number of germs on the floor between before and after application of housekeeping.

\section{ACKNOWLEDGEMENTS}

Thanks to Allah SWT for the gift that has been given. Thanks to all stakeholders who support the passage of this research.

\section{REFERENCES}

[1] Elfrida S., "Culture of patient safety and error characteristics of services: policy implications at one hospital in Jambi," National Public Health Journal, vol/issue: 6(2), pp. 67-76, 2011.

[2] Sanropie D., "Sanitation component of hospital for sanitation education institutions," Jakarta, Ministry of Health Republic Indonesia, 1989.

[3] Sumarno, "Factors that play a role in efforts to obtain an early diagnostic tool for tackling infectious diseases," Yogyakarta, Gadjah Mada University Press, 2006.

[4] Wijayanti S., "Identification and examination of the total number of bacteria," Pharmaceutical Journal, vol. 5, pp. 57-59, 2009.

[5] Baharutan A., et al., "The pattern of bacteria that cause nosocomial infections in the intensive care department of child BLU Prof. Dr. R. D. Kandou Manado,” E-Biomedic Journal (eBm), vol/issue: 3(1), pp. 412-417, 2015.

[6] Elizabeth R., et al., "Test the effectiveness of the antiseptic in perinatology unit General Hospital of Abdul Moeloek Bandar Lampung," Medical Journal of Lampung University, 2013.

[7] Fitriyastanti D., et al., "Some of the factors associated with the incidence of nosocomial surgical site infections in Semarang Hospitals Year 2003," Indonesian Journal of Public Health, vol/issue: 1(1), pp. 38-44, 2003.

[8] Wardani H. Y., "Analysis of the performance of nurses in nosocomial infection control in Bantul Muhammadiyah Hospital in Yogyakarta," Public Health Journal, vol/issue: 6(3), pp. 174-189, 2012.

[9] Harianto, "Nosocomial Infection and Universal Awareness," Microbiology Journal, vol/issue: 6(1), pp. 21-37, 2004.

[10] Laily W., "Specific Sanitation in Hospital Environment," Environmental Health Jounal, vol/issue: 3(2), pp. 49-53, 2009.

[11] Schmieg S., "Health Threat, Nosocomial Infection," Microbiology Journal, vol/issue: 2(3), pp. 11-25, 2007.

[12] Krisetyowati N. and Utomo M., "The effectiveness of refisol doses to decrease number of bacteria on the floor of the disease wards in public hospitals Karanganyar 2003," Unimus Journal, vol/issue: 1(2), pp. 96-101, 2004. 
[13] Setiawan B., et al., "Differences in the effectiveness of various disinfectants against the number of microorganisms incubator in the neonatal ICU DR Sardjito Hospital," Health Technology Journal, vol/issue: 10(1), pp. 1-7, 2014.

[14] Weinstein R. A., "Contamination, Disinfection, and Cross-Colonization: Are Hospital Surfaces Reservoirs for Nosocomial Infection?" Oxford Journals Medicine and Health Clinical Infectious Disease, vol/issue: 39(8), pp. 1182-1189, 2004.

[15] Khan H. A., et al., "Nosocomial infections and their control strategies," Asian Pacific Journal of Tropical Biomedicine, vol/issue: 5(7), pp. 509-514, 2015.

[16] Sydnor E. R. M. and Perl T. M., "Hospital epidemiology and infection control in acute-care settings," Clinical Microbiology Reviews, vol/issue: 24(1), pp. 141-173, 2011.

[17] Revelas A., "Healthcare-associated infections: A public health problem," Nigerian Medical Journal, vol/issue: 53(2), pp. 59-64, 2012.

[18] Pica N. and Bouvier N. M., "Environmental factors affecting the transmission of respiratory viruses," Curr Opin Virol., vol/issue: 2(1), pp. 90-95, 2013.

[19] Dasgupta S., et al., "Nosocomial infections in the intensive care unit: Incidence, risk factors, outcome and associated pathogens in a public tertiary teaching hospital of Eastern India," Indian Journal of Critical Care Medicine, vol/issue: 19(1), pp. 14-20, 2015.

[20] Quinn M. M. and Henneberger P. K., "Cleaning and disinfecting environmental sufaces in health care: Toward an integrated framework for infection and occupational illness prevention," American Journal of Infection Control, vol/issue: 43(5), pp. 424-434, 2015.

[21] Minister of Health Republic of Indonesia Number: 1204/MENKES/SK/X/2004 about the Terms of Environmental Health Hospital, 2004.

[22] Mohammed M., et al., "Nosocomial infections: An overview," International Research Journal of Pharmacy, vol/issue: 5(1), pp. 7-12, 2014.

[23] Dancer S. J., "Controlling hospital-acquired infection: Focus in the role of the environment and new technologies for decontamination," Clinical Microbiology Reviews, vol/issue: 27(4), pp. 665-690, 2014.

[24] Singh M., et al., "Comparative efficacy evaluation of disinfectants routinely used in hospital practice: India," Indian Journal of Critical Care Medicine, vol/issue: 16(3), pp. 123-129, 2012.

[25] Nugraheni R., et al., "Nosocomial Infection in Setjonegoro Hospital Wonosobo District," Public Health Media, vol/issue: 11(1), pp. 94-100, 2012.

[26] Blenkharn J. I., "Standards of Clinical Waste Management in UK Hospital," Journal of Hospital Infection, vol. 62, pp. 300-303, 2006.

[27] Lee H. H., et al., "Microbial reduction efficacy of various disinfection treatments on fresh-cut cabbage," Food Science and Nutrition, vol/issue: 2(5), pp. 585-590, 2014.

[28] E. Tuladhar, et al., "Residual viral and bacterial contamination of surfaces after cleaning and disinfection," Applied and Environmental Microbiology, vol/issue: 78(21), pp. 7769-7775, 2012.

[29] Krisanti E., et al., "Differences in the effectiveness of a quaternary ammonium disinfectant phenol $1 \%$ to $1 \%$ in a decrease in the number of germs in the treatment room floor Kardinah Hospital Tegal City," Environmental Health Journal of Indonesia, vol/issue: 12(1), pp. 42-50, 2013.

[30] Q. Sholihah, “Good Housekeeping,” Malang, Brawijaya University Press, 2011.

[31] Laura Y. S., et al., "Microbial Contamination of Hospital Reusable Cleaning Towels," American Journal of Infection Control, pp. 1-4, 2013.

[32] Abdullah M. T. dan Hakim B. A., "The physical environment and the number of bacteria in indoor air public hospitals Haji Makassar, South Sulawesi," National Public Health Journal, vol/issue: 5(5), pp. 206-211, 2011.

[33] Wikansari N., "Total inspection of air bacteria and Staphylococcus aureus in inpatient room X hospital Semarang City," Public Health Journal, vol/issue: 1(2), pp. 384-392, 2012.

[34] Mehta Y., et al., "Guidelines for Prevention of Hospital Acquired Infections," Indian Journal of Critical Care Medicine, vol/issue: 18(3), pp. 149-163, 2014. 